\title{
Evaluation of Genetic Divergence in Spanish Bunch Groundnut (Arachis hypogaea Linn.) Genotypes
}

\author{
Saikat Gantait $^{1,2}$, Sunil Kumar Gunri ${ }^{3}$, Rajib Kundu ${ }^{1,3}$, Soumitra Chatterjee ${ }^{4}$ \\ ${ }^{1}$ All India Coordinated Research Project on Groundnut, Directorate of Research, Bidhan Chandra Krishi Viswavidyalaya, Kalyani, \\ Nadia, West Bengal 741235, India \\ ${ }^{2}$ Department of Genetics and Plant Breeding, Faculty of Agriculture, Bidhan Chandra Krishi Viswavidyalaya, Mohanpur, Nadia, \\ West Bengal 741252, India \\ ${ }^{3}$ Department of Agronomy, Faculty of Agriculture, Bidhan Chandra Krishi Viswavidyalaya, Mohanpur, Nadia, West Bengal 741252, \\ India \\ ${ }^{4}$ All India Coordinated Research Project on Integrated Farming Systems, Directorate of Research, Bidhan Chandra Krishi \\ Viswavidyalaya, Kalyani, Nadia, West Bengal 741235, India
}

\begin{abstract}
In our present study, we report the nature and degree of genetic diversity among 21 promising Spanish bunch groundnut genotypes of different agro-climatic regions, obtained from Directorate of Groundnut Research, Junagadh, Gujarat (India) during Kharif for 2015-16. The results obtained from analysis of variance showed that there was significant difference $(P<0.05)$ between the genotypes in terms of days to first flowering, days to maturity, 100-kernels weight, shelling percentage, sound matured kernel, and pod yield. The recorded data matrix on seven morphological traits were employed for Non-hierarchical Euclidean cluster analysis based on square Euclidian distance by Un-weighted Paired Group Arithmetic Average method. The 21 genotypes were grouped into four distinct non-overlapping clusters in a random sequence, indicating the presence of high dimension of genetic diversity. Pod yield as an economically important trait was found to be the key contributor towards the genetic divergence followed by days to maturity. Based on magnitude of divergence and performance towards yield and yield attributes, five genotypes (TG-75, AK-343, ICGV-07038, Girnar-3 and TCGS-1157) were selected for exploitation as parents in future breeding programs. Based on high yielding genotypes and large inter-cluster distances, a trial on crossing of the genotypes from cluster II with the genotypes of clusters IV and III, genotypes from cluster I with II emphasizing on selected five genotypes could result in wide spectrum of promising genetic variability, aiming at enhancement of groundnut yield.
\end{abstract}

Keywords Analysis of variance, Clustering, Mahalanobis D², Pod yield, Squared Euclidian distance

\section{INTRODUCTION}

Cultivated groundnut (Arachis hypogaea Linn.) is the predominant one out of 69 species described in the genus Arachis. It's a self-pollinated, annual, herbaceous legume that belongs to the family Fabaceae. This crop, evolved in Southern Bolivia to North-Western Argentina regions of South America (Wiess 2000), is widely grown under wet conditions in semi-arid regions of $>80$ countries including
Africa, Americas and Asia (Singh and Singh 1992) and have recourse both to human consumption as well as an important provenance of vegetative oil. The groundnut kernel serves a rich source of edible oil (48-50\%) as well as protein (25-28\%) (Janila et al. 2013). It is also a dietary source of vitamin E, niacin, falcin, calcium, phosphorus, magnesium, zinc, iron, riboflavin, thiamine and potassium (Stigter et al. 2006) that are ingested right away as fresh, baked or cooked kernels otherwise, oil isolated from the

Received March 30 2017; Revised May 26, 2017; Accepted June 11, 2017; Published September 1, 2017

*Corresponding author Saikat Gantait, saikatgantait@yahoo.com, Tel: +91-33-2582-8407, Fax: +91-33-2582-8407 
kernel is consumed as cooking oil. The haulms (vegetative portions of plant) of groundnut deliver superior quality hay as animal feed since these are enrich with protein and ensure enhanced deliciousness as well as assimilation rate in comparison to other forage (Singh et al. 2010a). Groundnut now ranks fifth and thirteenth in the world among oil producing and food crops, respectively (Mondal et al. 2009). World production of groundnut is increasing and has reached 43,915,365 tons (in the shell). In India, groundnut is grown on 4,685,000 ha with a production of $6,557,000$ tons and an average productivity of $13,996 \mathrm{hg} / \mathrm{ha}$ (FAOSTAT, http://www.fao.org/faostat/en/\#data/QC).

Cultivated groundnut is an allotetraploid (AABB, $2 n=$ $4 x=40$ ) having very narrow genetic diversity. Contrastingly, the diploid wild-type ancestors are inherently heterogeneous and preferably selected for cumulating stress resistant genes during adaptation to severe environments (Kochert et al. 1996; Subramania et al. 2000; Gimenes et al. 2002). The minimal level of variation in cultivated peanut has been accredited to three reasons or to combinations of those: (1) obstructions to gene flow from associated diploid species to domesticated peanut as a result of the polyploidization issue (Young et al. 1996); (2) fresh polyploidization, from one or a small number of individual(s) of each diploid parental species, combined with self-pollination (Halward et al. 1991); or (3) utilization of few leading breeding lines and few exotic germplasms in breeding programs, ensuing in a limited genetic base (Isleib and Wynne 1992). On the other hand, selection of genetically diverse parents, which is expected to develop superior and desirable segregants following crossing, enables the expansion of genetic base and development of superior genotypes (Gantait and Das 2009; Gantait et al. 2009). Majority of the economically important characters including pod yield and its components are amenable for genetic improvement through intense breeding among genetically diverse parents.

Keeping in view of the above genotypic aspects, the present investigation was carried out to know the nature and magnitude of genetic divergence in 21 groundnut genotypes for their incorporation in future hybridization program that would eventually help in development of groundnut varieties with higher pod yield.

\section{MATERIALS AND METHODS}

\section{Plant materials and site of experiment}

The Directorate of Groundnut Research (DGR), Gujarat, India, collected a total of 21 Spanish bunch-type promising genotypes from different agro-climatic zones/research centers of India. We've obtained these genotypes from the DGR (the details of the genotype collection sites have been updated in Table 1) and used as the experimental materials for the current analysis. The randomized block design was followed in the current trial at the In-Check C-block

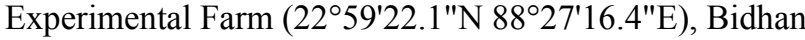
Chadra Krishi Viswavidyalaya, Kalyani, West Bengal situated at New Alluvial Zone of India, during Kharif (July to October for consecutive two years i.e. 2015-2016) season under non- irrigated condition. In each replication every genotypes was sown in four rows of $5 \mathrm{~m}$ length and $1.5 \mathrm{~m}$ width with a spacing of $30 \mathrm{~cm}$ between the rows and $10 \mathrm{~cm}$ between the plants within rows. All the advocated agronomic cultural practices and plant protection measures

Table 1. Summary of 21 Spanish bunch groundnut (Arachis hypogaea Linn.) genotypes used in the present experiment.

\begin{tabular}{lll}
\hline \hline \multicolumn{1}{c}{ Genotype } & Breeding center & \multicolumn{1}{c}{ State in India } \\
\hline AK-335 & Akola & Maharashtra \\
CTMG-11 & Chintamani & Karnataka \\
KDG-197 & Digraj & Maharashtra \\
JCG-3005 & Jagtial & Telengana/Andrapradesh \\
AK-343 & Akola & Maharashtra \\
Dh-235 & Dharwad & Karnataka \\
J-86 & Junagadh & Gujarat \\
Dh-241 & Dharwad & Karnataka \\
JCG-2141 & Jagtial & Telengana/Andrapradesh \\
ICGV-07038 & ICRISAT & Telengana/Andrapradesh \\
ICGV-06138 & ICRISAT & Telengana/Andrapradesh \\
TG-74 & Trombay & Maharashtra \\
TVG-0856 & Vriddhachalam & Tamil Nadu \\
TG-75 & Trombay & Maharashtra \\
LGN-163 & Latur & Maharashtra \\
VG-315 & Vriddhachalam & Tamil Nadu \\
TCGS-1157 & Tindivanam & Tamil Nadu \\
OG-52-1 & Bhubaneswar & Orissa \\
Girnar-3 & Junagadh & Gujarat \\
TAG-24 & Trombay & Maharashtra \\
R-2001-2 & Raichur & Karnataka \\
\hline
\end{tabular}


were practiced whenever required in raising the crop. Hand weeding was carried out following 15 days of sowing and successively at 20 days interims to warrant nominal crop-weeds competition. There was no usage of chemical fertilizers, herbicides or pesticides.

\section{Collection of data}

Morphological data and yield data were recorded from every genotype. Ten randomly selected plants from respective row (i.e. 40 plants in each plot) of each genotype per replication for seven characters viz., days to first flowering, days to $50 \%$ flowering, days to maturity, 100-kernels weight (g), shelling percentage, sound matured kernel (SMK) (\%), pod yield $(\mathrm{kg} / \mathrm{ha})$ were sampled and their mean values were used for the statistical analysis. Nevertheless, days to first flowering, days to $50 \%$ flowering and days to maturity were documented on the plot basis.

\section{Statistical analysis}

Collected data (replication-wise) for respective attributes were put through analysis of variance (ANOVA) using the SPSS (Version 11, SPSS Inc. Chicago, USA) software package. The collected data were assessed based on the Duncan's multiple range test (DMRT) (Duncan 1955) at a certain $P$ value of 0.05 using SPSS. Using arc sine, percentage values were changed before calculating ANOVA and then were altered back to the primary scale (Compton 1994). Wilk's criteria were considered to estimate the cumulative influences of attributes towards variations among the genotypes. Subsequently, the Mahalanobis D ${ }^{2}$ (Mahalanobis 1936) statistics was referred

Table 2. Mean values ${ }^{\mathrm{z})}$ of yield and yield contributing characters in 21 Spanish bunch groundnut (Arachis hypogaea Linn.) genotypes.

\begin{tabular}{|c|c|c|c|c|c|c|c|}
\hline Genotype & $\begin{array}{c}\text { First flowering } \\
\text { (days) }\end{array}$ & $\begin{array}{c}50 \% \text { flowering } \\
\text { (days) }\end{array}$ & $\begin{array}{l}\text { Days to } \\
\text { maturity }\end{array}$ & $\begin{array}{c}100-\mathrm{KW} \\
(\mathrm{g})\end{array}$ & $\begin{array}{l}\text { Shelling } \\
(\%)^{\mathrm{x})}\end{array}$ & $\begin{array}{l}\text { SMK } \\
(\%)^{\mathrm{x})}\end{array}$ & $\begin{array}{c}\text { Pod yield } \\
\text { (kg/ha) }\end{array}$ \\
\hline AK-335 & $24.3 \mathrm{~d}^{\mathrm{y})}$ & $32.5 \mathrm{a}$ & $112.8 \mathrm{def}$ & $40.9 \mathrm{fg}$ & $67.9 \mathrm{~d}-\mathrm{g}$ & $87.0 \mathrm{cde}$ & $2855.5 \mathrm{ab}$ \\
\hline CTMG-11 & $25.0 \mathrm{bcd}$ & $32.3 \mathrm{a}$ & $116.0 \mathrm{a}-\mathrm{d}$ & $38.5 \mathrm{~h}$ & 70.1a-f & $89.3 \mathrm{abc}$ & $1825.8 \mathrm{fg}$ \\
\hline KDG-197 & $25.5 \mathrm{bcd}$ & $32.5 \mathrm{a}$ & $119.3 \mathrm{a}$ & $44.7 \mathrm{a}-\mathrm{d}$ & 69.4a-g & 86.0de & $2774.0 \mathrm{ab}$ \\
\hline JCG-3005 & $24.5 \mathrm{~cd}$ & $32.0 \mathrm{a}$ & $114.3 \mathrm{cde}$ & $39.4 \mathrm{gh}$ & $67.0 \mathrm{~g}$ & $87.5 b-e$ & $1625.0 \mathrm{~g}$ \\
\hline AK-343 & $29.3 \mathrm{a}$ & $33.8 \mathrm{a}$ & 116.3a-d & $40.8 \mathrm{fg}$ & 70.9abc & $90.8 \mathrm{a}$ & $2604.8 \mathrm{bc}$ \\
\hline Dh-235 & $27.3 \mathrm{ab}$ & $33.5 \mathrm{a}$ & $115.8 \mathrm{a}-\mathrm{d}$ & $38.3 \mathrm{~h}$ & $69.8 \mathrm{a}-\mathrm{g}$ & $86.0 \mathrm{de}$ & $2131.5 \mathrm{ef}$ \\
\hline $\mathrm{J}-86$ & $24.5 \mathrm{~cd}$ & $32.0 \mathrm{a}$ & $115.3 \mathrm{~b}-\mathrm{e}$ & $45.8 \mathrm{ab}$ & 68.9a-g & 89.0a-d & $2541.8 b c$ \\
\hline Dh-241 & $25.3 \mathrm{bcd}$ & $31.8 \mathrm{a}$ & $110.3 \mathrm{fg}$ & $42.5 \mathrm{def}$ & $67.3 \mathrm{fg}$ & 87.0cde & $2534.5 b c$ \\
\hline JCG-2141 & $27.0 \mathrm{~b}$ & $32.3 \mathrm{a}$ & $114.8 \mathrm{cde}$ & $42.4 \mathrm{def}$ & $68.1 \mathrm{c}-\mathrm{g}$ & $89.5 \mathrm{abc}$ & $2318.8 \mathrm{de}$ \\
\hline ICGV-07038 & $24.3 d$ & $31.5 \mathrm{a}$ & $118.5 \mathrm{ab}$ & $39.2 \mathrm{gh}$ & $68.2 \mathrm{~b}-\mathrm{g}$ & $88.5 \mathrm{a}-\mathrm{e}$ & $2340.8 \mathrm{de}$ \\
\hline ICGV-06138 & $26.0 \mathrm{bcd}$ & $31.8 \mathrm{a}$ & 116.3a-d & $41.4 \mathrm{efg}$ & $67.5 \mathrm{efg}$ & 87.0cde & $2785.0 \mathrm{ab}$ \\
\hline TG-74 & $25.8 \mathrm{bcd}$ & $31.3 \mathrm{a}$ & $112.0 \mathrm{ef}$ & $45.5 \mathrm{abc}$ & $71.0 \mathrm{abc}$ & 89.3abc & $3080.5 b$ \\
\hline TVG-0856 & $25.5 \mathrm{bcd}$ & $31.5 \mathrm{a}$ & $116.8 \mathrm{abc}$ & $43.3 \mathrm{cde}$ & $68.9 \mathrm{a}-\mathrm{g}$ & $88.0 \mathrm{a}-\mathrm{e}$ & $2769.8 \mathrm{ab}$ \\
\hline TG-75 & $26.3 \mathrm{bcd}$ & $31.3 \mathrm{a}$ & $114.0 \mathrm{cde}$ & $44.7 \mathrm{a}-\mathrm{d}$ & $71.5 \mathrm{a}$ & $87.0 \mathrm{cde}$ & $3757.0 \mathrm{a}$ \\
\hline LGN-163 & $25.5 \mathrm{bcd}$ & $31.3 \mathrm{a}$ & $116.5 \mathrm{abc}$ & $44.2 \mathrm{a}-\mathrm{d}$ & $69.2 \mathrm{a}-\mathrm{g}$ & $85.5 \mathrm{e}$ & $2559.0 \mathrm{bc}$ \\
\hline VG-315 & $25.3 \mathrm{bcd}$ & $32.0 \mathrm{a}$ & $115.3 \mathrm{~b}-\mathrm{e}$ & $44.3 \mathrm{a}-\mathrm{d}$ & $70.8 \mathrm{a}-\mathrm{d}$ & $90.3 \mathrm{ab}$ & $2059.5 \mathrm{ef}$ \\
\hline TCGS-1157 & $24.5 \mathrm{~cd}$ & $33.5 \mathrm{a}$ & $116.0 \mathrm{a}-\mathrm{d}$ & $46.5 \mathrm{a}$ & $71.5 \mathrm{a}$ & $87.8 \mathrm{~b}-\mathrm{e}$ & $3686.5 \mathrm{a}$ \\
\hline OG-52-1 & $24.5 \mathrm{~cd}$ & $32.5 \mathrm{a}$ & $108.0 \mathrm{gh}$ & $43.6 \mathrm{~b}-\mathrm{e}$ & $71.2 \mathrm{ab}$ & $87.8 \mathrm{~b}-\mathrm{e}$ & $2763.0 \mathrm{ab}$ \\
\hline Girnar-3 & $25.8 \mathrm{bcd}$ & $31.8 \mathrm{a}$ & $106.3 \mathrm{~h}$ & $44.5 \mathrm{a}-\mathrm{d}$ & $70.6 a-d$ & $88.5 \mathrm{a}-\mathrm{e}$ & $3480.3 \mathrm{a}$ \\
\hline TAG-24 & $26.8 \mathrm{bc}$ & $31.8 \mathrm{a}$ & $114.0 \mathrm{cde}$ & $44.6 \mathrm{a}-\mathrm{d}$ & $71.2 \mathrm{ab}$ & $90.0 \mathrm{abc}$ & $2785.3 \mathrm{ab}$ \\
\hline R-2001-2 & $26.8 b c$ & $31.5 \mathrm{a}$ & $116.3 \mathrm{a}-\mathrm{d}$ & $44.0 \mathrm{bcd}$ & 70.4a-e & 88.3a-e & $3592.5 \mathrm{a}$ \\
\hline
\end{tabular}

${ }^{2)}$ Data represent mean of four replicates with 40 samples per genotype.

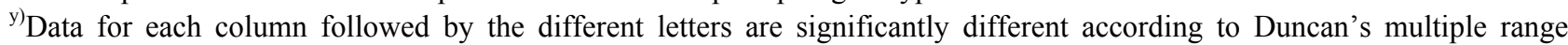
test (Duncan 1955) at the 0.05 probability level.

${ }^{\mathrm{x})}$ Data expressed as percentage were transformed using arc sine prior to ANOVA and converted back to the original scale for demonstration in the table (Compton 1994). 
for the assessment of genetic diversity. Grouping of the genotypes was performed following the Tocher's method (Rao 1952) considering that the genotypes within the cluster have lesser $\mathrm{D}^{2}$ values amid themselves in comparison to those from distinctive clusters. Squared Euclidian distance between genotypes was calculated from the standardized data matrix by Unweighted Pair Group Method using Arithmetic Averages (UPGMA) method, subsequently, the genotypes were grouped into different clusters using Statistical Analysis System (SAS).

\section{RESULTS}

\section{Mean performance}

The summary statistics of the morphological characters of all the genotypes (explained in Table 2) signified broad variation in respect to all the characters under consideration. The ANOVA computed for seven agro-morphological traits revealed the presence of significant differences $(P=0.05)$ on days to first flowering, days to maturity, 100-kernels weight, shelling percentage, SMK, pod yield. However, non-significant difference was observed on days to $50 \%$ flowering (Table 2). The mean performance of groundnut genotypes showed narrow range of means for studied agro-morphological traits except for pod yield, the most economically important trait (Table 2). In this study genotypes showed narrow range of variation for majority of the attributes, for instance, shelling percentage ranged from 67.0 to 71.5 with a mean of $69.6 \%$, SMK ranged from 85.5 to 90.8 with a mean of $88.0 \%$, first flowering ranged from 24.3 to 29.3 with a mean of 25.7 days, $50 \%$ flowering ranged from 31.3 to 33.8 with a mean of 32.1 days and 100-kernels weight ranged from 38.3-46.5 with a mean of $42.8 \mathrm{~g}$. On the other hand, a wide range of mean was recorded for pod yield between 1,625-3,757 with a mean of $2,708.1 \mathrm{~kg} / \mathrm{ha}$.

\section{Cluster composition}

In the present study, based on the $\mathrm{D}^{2}$ values 21 genotypes were grouped into four distinctive non-hierarchical clusters. The components of these four clusters plus their origin are described in Table 3. Cluster analysis involves three key steps, i.e. computing the distances, associating the clusters then selecting the accurate figure of clusters. Out of the four clusters in our study, cluster II was the largest one containing 14 genotypes, cluster I having 3 genotypes, cluster III and IV were comprised of 2 genotypes each (Table 3). A dendrogram was also obtained from the non-hierarchical cluster analysis based on Euclidean's method that grouped the groundnut genotypes into four distinct non-overlapping clusters at a distance of 400 (Fig. 1).

\section{Inter- and intra-cluster distances $\left(D=\sqrt{ } \mathbf{D}^{2}\right)$}

Mean values of intra as well as inter-cluster distances among the genotypes revealed that the individual clusters possessed high values of intra-cluster distances. The highest intra-cluster distance was observed in cluster IV (5.822) (comprising TCGS-1157 and TAG-24) whereas the lowest distance value was recorded in cluster III (3.316) (comprising OG-52-1 and Girnar-3) (Table 4). The most plausible explanation for relatively short genetic distances amid OG-52-1 and Girnar-3 genotypes is that they might have descended from a mutual ancestral population. According to Singh et al. (2010b), the genotypes, inside individual cluster, having greater degree of divergence would generate more appropriate breeding materials for attaining the highest genetic advance. The genotypes TCGS-1157 and TAG-24 recorded the highest distance

Table 3. Clustering pattern of 21 Spanish bunch groundnut (Arachis hypogaea Linn.) genotypes.

\begin{tabular}{lcccc}
\hline \multicolumn{1}{c}{ Cluster No. } & I & II & III & IV \\
\hline No. of population & 3 & 14 & 2 \\
Names of genotypes & AK-335, TG-75, & CTMG-11, KDG-197, JCG-3005, AK-343, & OG-52-1, & TCGS-1157, \\
& R-2001-2 & Dh-235, J-86, Dh-241, JCG-2141, & Girnar-3 & TAG-24 \\
& & ICGV-07038, ICGV-06138, TG-74, & \\
& & TVG-0856, LGN-163, VG-315 & \\
\hline
\end{tabular}




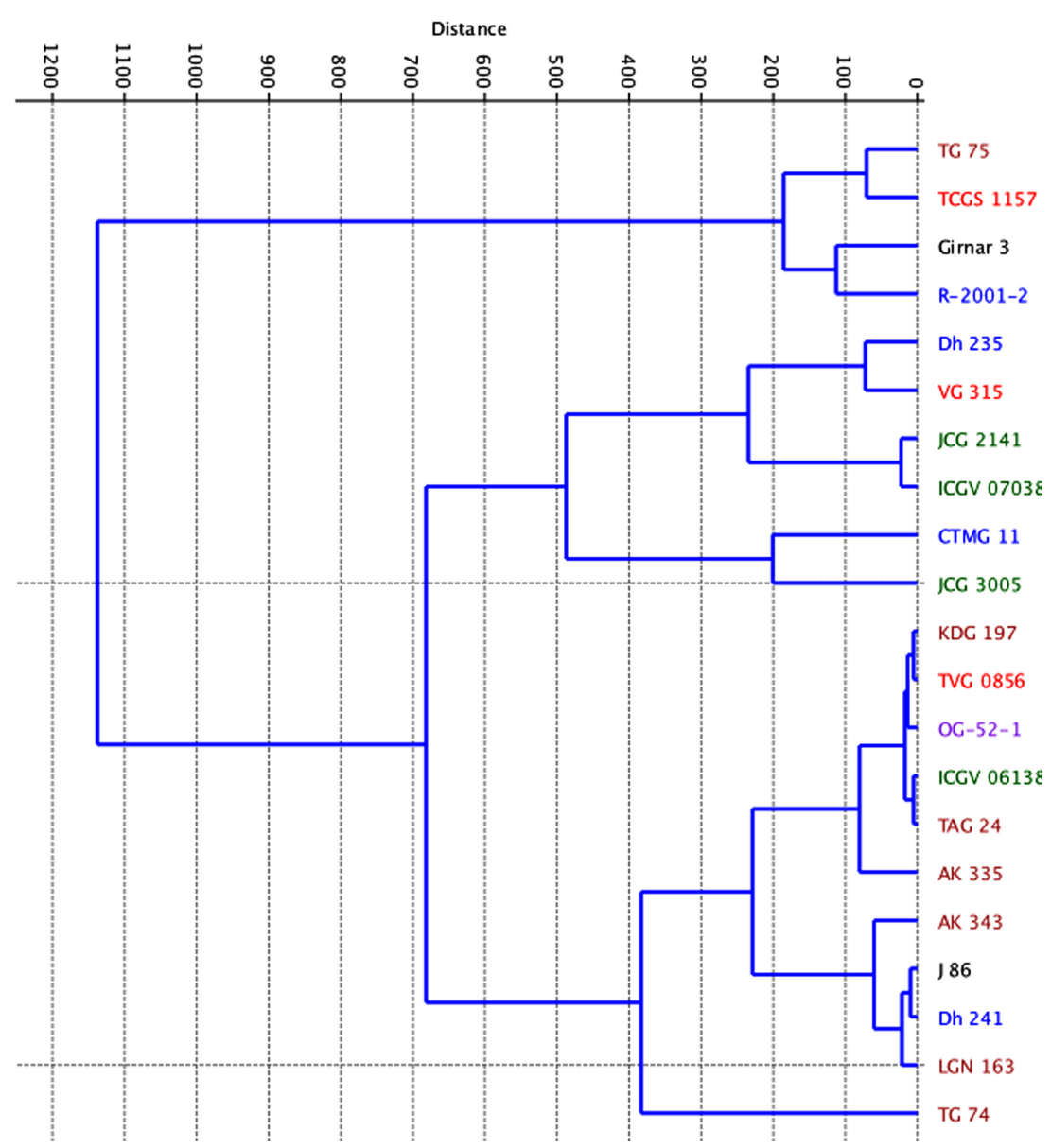

Fig. 1. Dendrogram representing classification/clustering of 21 Spanish bunch groundnut (Arachis hypogaea Linn.) genotypes on seven different quantitative characters based on Squared Euclidian distance matrix.

Table 4. Intra- (diagonal) and inter-cluster average distance for seven quantitative characters of 21 Spanish bunch groundnut (Arachis hypogaea Linn.) genotypes.

\begin{tabular}{ccccc}
\hline \hline Cluster No. & I & II & III & IV \\
\hline I & $\mathbf{4 . 2 9 4}$ & 5.800 & 5.070 & 4.339 \\
II & & $\mathbf{4 . 7 4 5}$ & 6.148 & 6.219 \\
III & & $\mathbf{3 . 3 1 6}$ & 5.470 \\
IV & & & $\mathbf{5 . 8 2 2}$ \\
\hline
\end{tabular}

within the same cluster (IV). However, the inter-cluster distances were higher than that of the intra cluster ones with an exception in case of cluster IV (Table 4). Such higher inter cluster distances indicates wide extent of genetic diversity among the genotypes of cluster I, II and III in particular. Another notably higher inter-cluster distance (6.148) was observed between cluster II and cluster III. The clusters that are isolated by the maximum statistical distance display the greatest divergence for variability. Interestingly, the least distance (4.339) was displayed between cluster I and cluster IV.

\section{Cluster means for various characters}

Incomprehensible differences were recorded in the intra-cluster group means for six attributes out of seven (Table 5). Both cluster I (comprising 3 genotypes) and 
Table 5. Cluster means values of seven different quantitative characters of 21 Spanish bunch groundnut (Arachis hypogaea Linn.) genotypes.

\begin{tabular}{cccccccc}
\hline \hline Cluster & $\begin{array}{c}\text { First flowering } \\
\text { (days) }\end{array}$ & $\begin{array}{c}50 \% \text { flowering } \\
\text { (days) }\end{array}$ & $\begin{array}{c}\text { Days to } \\
\text { maturity }\end{array}$ & $\begin{array}{c}\text { 100-kernel } \\
\text { weight }(\mathrm{g})\end{array}$ & $\begin{array}{c}\text { Shelling } \\
(\%)\end{array}$ & $\begin{array}{c}\text { SMK }^{2)} \\
(\%)\end{array}$ & $\begin{array}{c}\text { Pod yield } \\
(\mathrm{kg} / \mathrm{ha})\end{array}$ \\
\hline I & 25.8 & 31.8 & 114.3 & 43.2 & 56.8 & 69.3 & 3401.7 \\
II & 25.8 & 32.1 & 115.5 & 42.1 & 56.3 & 69.9 & 2425.0 \\
III & 25.1 & 32.1 & 107.1 & 44.0 & 57.4 & 69.8 & 3121.6 \\
IV & 25.6 & 32.6 & 115.0 & 45.6 & 57.6 & 70.6 & 3235.9 \\
\hline
\end{tabular}

${ }^{2)}$ SMK: stands for sound matured kernel.

cluster II (containing 14 genotypes) displayed highest cluster mean value (25.8) for days to first flowering whereas, cluster IV (with two genotypes) showed highest cluster mean of 32.6 for days to $50 \%$ flowering. In case of days to maturity, cluster II recorded the highest mean of 115.5. The superiority of cluster IV over the other three was also evident in case of 100-kernel weight (g) and SMK percentage, which were recorded as high as 45.6 and 70.6, respectively. The most significant differences among the cluster means were observed in case of pod yield wherein cluster I recorded maximum mean value of $3,401.7 \mathrm{~kg} / \mathrm{ha}$. Interestingly, cluster II comprising highest number of genotypes and displaying highest mean days to maturity recorded minimum mean value of pod yield $(2,425 \mathrm{~kg} / \mathrm{ha})$. Cluster IV, having least number of genotypes but securing maximum mean value of 100-kernel weight (g) and SMK percentage, ranked second based on mean pod yield $(3,235.9)$.

\section{Contribution of various characteristics to total divergence}

The percent contribution assay of all the seven traits concerning the influence of overall genetic divergence specified that pod yield was the highest contributor with $70.47 \%$ out of 100 . Pod yield was followed by days to maturity (11.43\%), SMK (\%) (7.62\%), 100-kernel weight $(5.24 \%)$, shelling (\%) $(2.86 \%)$ and days to first flowering (2.38\%) (Table 6). It was interesting to observe in our study that $50 \%$ flowering showed no contribution towards genetic diversity. It was also evident that pod yield alone, being the prime and economically most desirable trait, played the key role to establish genetic divergence among groundnut genotypes. The other five traits merely con-
Table 6. Percent contribution of each quantitative character to genetic divergence 21 Spanish bunch groundnut (Arachis hypogaea Linn.) genotypes.

\begin{tabular}{|c|c|c|}
\hline Characters & $\begin{array}{l}\text { No. of } \\
\text { first rank }\end{array}$ & $\begin{array}{l}\text { Contribution } \\
\text { (in percent) }\end{array}$ \\
\hline First flowering & 5 & 2.38 \\
\hline $50 \%$ flowering & 0 & 0 \\
\hline Days to maturity & 24 & 11.43 \\
\hline 100-kernels weight (g) & 11 & 5.24 \\
\hline Shelling (\%) & 6 & 2.86 \\
\hline $\operatorname{SMK}^{2)}(\%)$ & 16 & 7.62 \\
\hline Pod yield (kg/ha) & 148 & 70.47 \\
\hline Total & 210 & 100 \\
\hline
\end{tabular}

${ }^{\mathrm{z}} \mathrm{SMK}$ : stands for sound matured kernel.

tributed $29.53 \%$ with days to maturity being the second major contributor of total divergence.

\section{Promising genotypes from diverse clusters}

The proficient genotypes belonging to diverse clusters were selected based on the mean performance for different traits for their exploitation as the parents in hybridization program. The selected genotypes are enlisted according to their merit for six different characters under study except days to $50 \%$ flowering (Table 7) since it was not a contributor during assessment of genetic divergence (Table 6). The promising genotypes are TG-75 (with high pod yield and shelling percentage) from cluster I, AK-343 (with high SMK \%), and ICGV-07038 (with early flowering) from cluster II, Girnar-3 (with early maturity) from cluster III, and finally TCGS-1157 (with high 100-kernel weight, high shelling percentage and high pod yield) from cluster IV. 
Table 7. Promising genotypes of Spanish bunch groundnut (Arachis hypogaea Linn.) selected from diverse clusters for different yield attributing characters.

\begin{tabular}{cll}
\hline \hline Cluster no. & Genotype(s) & \multicolumn{1}{c}{ Trait(s) } \\
\hline I & TG-75 & Pod yield $(3757 \mathrm{~kg} / \mathrm{ha})$, Shelling (\%) (71.5) \\
II & AK-343 & SMK $(\%)(90.8)$ \\
& ICGV-07038 & First flowering (24.3 days) \\
III & Girnar-3 & Early maturity (106.3 days) \\
IV & TCGS-1157 & $100-\mathrm{KW}^{\mathrm{z})}(\mathrm{g})(46.6)$, Shelling (\%) (71.5), Pod yield (kg/ha) (3686.5) \\
\hline
\end{tabular}

Note: $50 \%$ flowering was not considered since it was not significant contributor during assessment of genetic divergence. ${ }^{\mathrm{z})} \mathrm{SMK}$ and $\mathrm{KW}$ stand for sound matured kernel and kernel weight, respectively.

\section{DISCUSSION}

In this current report, genetic diversity was studied amongst 21 groundnut genotypes based on seven quantitative attributes. The ANOVA outcome indicated the presence of variability among the groundnut genotypes on studied traits that can be exploited through selection to improve the crop for desired traits in further groundnut breeding program. The cumulative influences of all the seven attributes were examined by the Wilk's criteria that signified the variations among the genotypes. In the present study, grouping of the genotypes was performed following the Tocher's method (Rao 1952) considering that the genotypes within the cluster have lesser $\mathrm{D}^{2}$ values amid themselves in comparison to those from distinctive clusters. The genotypes were randomly distributed in distinct clusters. The configuration of genotype distribution among four clusters established the presence of divergence amid the genotypes, which likewise was specified by the ANOVA. Nevertheless, the genotype distribution in four clusters was independent of high yield and its attributes, the key parameters for which the genotypes were screened. The probable reason for such dissimilarity among genotypes might be attributed to the divergent genetic background of the parents and different gene assemblies that govern the adaptive characters. This is in contrary to the earlier report of Vasanthi et al. (2015), which revealed that the distribution of genotypes into different clusters was related to the objective with which the genotypes were bred. Clustering pattern showed significant impact on selection of parents and the cross combinations aiming to create maximum possible variability for various characters.
For further selection and improvement, the genotypes having high divergence values selected from any cluster can be included in hybridization scheme (Raghuwanshi et al. 2015).

In our study, it was observed that cluster II and cluster IV are highly dissimilar so as cluster II and cluster III suggesting that the genotypes from these two groups could be assessed for their combining ability and could be used as parents in heterosis breeding programs in groundnut as suggested by Betrán et al. (2003) in maize and Mahmuda et al. (2008), in Brassica. Genotypes that are separated by more statistical distance can be selected from those inter-clusters for their utilization in hybridization program (Maity et al. 2015). This statement is corroborated by the report of Bhakal and Lal (2015) who suggested that crossing between the groundnut genotypes allied to the cluster pairs cleaved apart by higher inter-cluster distances might develop anticipated transgressive segregates that eventually opens up the opportunity for identification of superior genotypes in successive generations. Our results and subsequent recognition of divergent groundnut accessions having high pod yield could be suitable in breeding for genetic improvement. Additive gene effects will play a primary role in inheritance of quantitative traits if there are less divergent germplasm lines and adapted lines (Isleib and Wynne 1983). With the expansion of diversity between parents the dominance effects and epistatic variations start to play substantial roles in the inheritance of quantitative traits (Halward and Wynne 1991). In case of self-pollinated crop such as peanut, this would have inferences during determination of an apt parent selection scheme. 
It further evidently appears from the above results that there was wide diversity from one cluster to the other in respect of cluster means for all seven traits especially pod yield, the most economically important attribute. This situation indicates that the genotypes that are markedly different in their mean performance for various characters were separated into different clusters. For the selection of desirable recombinants in the succeeding populations of groundnut a crossing scheme might be planned among the genotypes those belong to the cluster pairs with large inter-cluster distance and possessing high cluster means for single or multiple traits. Similar suggestions were also advocated by Gupta and Vachhani (2015) in Virginia type groundnut. According to Suneetha et al. (2012), the statistics of proportional contribution of different quantitative traits towards divergence assist the breeder for selection of parents for hybridization and in further advance generations. The efficacy of pod yield to be the major contributor in our study corroborates with the earlier reports on legumes. Therefore, it is logical that emphasis should be given on pod yield and days to maturity during selection of parents for hybridization i.e. selection of genotypes as divergent parents based on two traits may lead to broad spectrum of favourable genetic variability for yield improvement in groundnut (Gupta et al. 2015). Our results are in consistency with those of the previous reports on groundnut (Sumathi and Muralidharan 2008; Sonone and Thaware 2009; Sonone et al. 2011).

The variability parameters for yield and component traits in some of newly developed groundnut genotypes which have not been reported earlier by the researchers, will be helpful for harnessing present variability among them which in turn can support the ongoing and future groundnut breeding programs. It could be established that all the genotypes were observed to be divergent. Five highly divergent genotypes that showed significant performance for assorted characters under study have been identified and could be endorsed for crossing with other genotypes of the clusters exhibiting high inter-cluster distances. It's a well-known statistics that, more the genetically diverse parents employed in hybridization scheme, higher will be the probabilities of attaining heterotic hybrids and broad-spectrum variability in segregating populations. Furthermore, there is a probability that the most productive hybrids might derive from high yielding parents having a high genetic diversity. Hence, in our study, based on high yielding genotypes and large inter-cluster distances, a trial on crossing of the genotypes from cluster II with the genotypes of clusters IV and III, genotypes from cluster I with II emphasizing on TG-75, AK-343, ICGV-07038, Girnar-3 and TCGS-1157 could be logical. The outcome might result in wide spectrum of promising genetic variability aiming at enhancement of groundnut yield.

\section{ACKNOWLEDGEMENTS}

We, the authors, are thankful to the Directorate of Groundnut Research, ICAR, Junagadh, Gujarat for assisting us with the groundnut germplasms and financial support. We further appreciate our field assistants Mr. Tapan Chakrabarty and Mr. Kartick Ch. Nath for their immense help during field experiments.

\section{REFERENCES}

Betrán FJ, Ribaut JM, Beck D, Gonzalez de León D. 2003. Genetic diversity, specific combining ability and heterosis in tropical maize under stress and nonstress environments. Crop Sci. 43: 797-806.

Bhakal M, Lal GM. 2015. Studies on genetic diversity in groundnut (Arachis hypogaea L.) germplasm. J. Plant Sci. Res. 2: 128.

Compton ME. 1994. Statistical methods suitable for the analysis of plant tissue culture data. Plant Cell Tiss Organ Cult. 37: 217-242.

Duncan DB. 1955. Multiple range and multiple F test. Biometrics 11: 1-42.

Gantait S, Das PK. 2009. Genetic divergence, adaptability and genotypic response to YMV in blackgram. Legume Res. 32: 79-85.

Gantait S, Mandal N, Das PK. 2009. Diversity of blackgram (Vigna mungo L. Hepper) genotypes assessed through morphological and biochemical approach. J. Tropical Agric. 47: 80-83. 
Gimenes MA, Lopes CR, Valls JFM. 2002. Genetic relationship among Arachis species based on AFLP. Genet. Mol. Biol. 25: 349-353.

Gupta RP, Vachhani JH, Kachhadia VH, Vaddoria MA, Bhatiya VJ. 2015. Genetic divergence in Virginia groundnut (Arachis hypogaea L.). Electronic J. Plant Breed. 6: 566-569.

Gupta RP, Vachhani JH. 2015. Genetic divergence studies in Virginia groundnut (Arachis hypogaea L.). Trend. Biosci. 8: 543-547.

Halward TM, Stalker HT, Larue EA, Kochert G. 1991. Genetic variation detectable with molecular markers among unadapted germplasm resources of cultivated peanut and related wild species. Genome 34: 1013-1020.

Halward TM, Wynne JC. 1991. Generation means analysis for productivity in two diverse peanut crosses. Theor. Appl. Genet. 82: 784-792.

Isleib TG, Wynne JC. 1992. Use of plant introductions in peanut improvement, p. 75-116. In: HL. Shands (ed.). Use of Plant Introductions in Cultivar Development Volume 2. Crop Science Society of America, Madison.

Isleib TG, Wynne JC. 1983. Heterosis in testcrosses of 27 exotic peanut cultivars. Crop Sci. 23: 832-841.

Janila P, Nigam SN, Pandey MK, Nagesh P, Varshney RK. 2013 Groundnut improvement: use of genetic and genomic tools. Frontiers Plant Sci. 4: 23.

Kochert G, Stalker HT, Gimenes M, Galgaro L, Lopes CR, Moore K. 1996. RFLP and cytogenetic evidence on the origin and evolution of allotetraploid domesticated peanut, Arachis hypogaea (Leguminosae). Am. J. Bot. 83: 1282-1291.

Mahalanobis PC. 1936. On the generalized distance in statistics. Proc. Nat. Inst. Sci. (India) 2: 49-55.

Mahmuda F, Rasulb MG, Rahima MA. 2008. Genetic diversity analysis in some advanced lines of Brassica napus. Science Asia 34: 432-434.

Maity S, Das S, Saha BC. 2015. Study of genetic diversity for grain yield and other agronomic traits of bread wheat (Triticum aestivum 1.) in acid soils of West Bengal. Electronic J. Plant Breed. 55-60.

Mondal S, Sutar SR, Badigannavar AM. 2009. Assessment of genetic diversity in cultivated groundnut (Arachis hypogaea L.) with differential responses to rust and late leaf spot using ISSR markers. Indian J. Genet. Plant
Breed. 69: 219-224.

Raghuwanshi SS, Kachhadia VH, Vachhani JH, Jivani LL, Patel MB. 2015. Genetic divergence in ground nut (Arachis hypogaea L.). Electronic J. Plant Breed. 145-151.

Rao CR. 1952. Advanced Statistical Methods In Biometrical Research., John Wiley And Sons, New York. pp. 357-369.

Singh S, Singh AL, Kalpana S, Misra S. 2010a. Genetic diversity for growth, yield and quality traits in groundnut (Arachis hypogaea L.). Indian J. Plant Physiol. 15: 267-271.

Singh U, Singh B. 1992. Tropical grain legumes as important human foods. Econ. Bot. 46: 310-321.

Singh BN, Vishwakarma SR, Singh VK. 2010b. Character association and path analysis in elite lines of wheat (Triticum aestivum L.). Plant Archives 10: 845-847.

Sonone NG, Thaware BL. 2009. Study on genetic diversity in groundnut. Ann. Agric. Res. 26: 1-4.

Sonone NG, Thaware BL, Bhave SG, Jadhav BB, Joshi GD, Dhekale JS. 2011. Multivariate studies in groundnut (Arachis hypogaea L.). J. Oilseeds Res. 28: 24-28.

Stigter K, Orivaldo B, Kumar PV, Prasad PVV. 2006. Agrometeorology and groundnut production. Retrieved from http://www.agrometeorology.org/files.

Subramania V, Gurtu S, Nageswara Rao RC, Nigam SN. 2000. Identification of DNA polymorphism in cultivated groundnut using random amplified polymorphic DNA (RAPD) assay. Genome 43: 656-660.

Sumathi P, Muralidharan V. 2008. Genetic divergence analysis in some bold seeded genotypes of groundnut (Arachis hypogaea L.). J. Oilseeds Res. 25: 1-3.

Suneetha N, Vasanthi RP, Sudhakar P, Raja Reddy K. 2012. Genetic diversity analysis among released and pre-release cultures in groundnut. Leg. Res. 36: 208-213.

Vasanthi RP, Suneetha N, Sudhakar P. 2015. Genetic diversity based on physiological attributes among released and pre-release cultures of groundnut (Arachis hypogaea L.). Leg. Res. 38: 47-50.

Weiss EA. 2000. Oilseed Crops. London: Blackwell Science. Young ND, Weeden NF, Kochert G. 1996. Genome mapping in legumes (Family Fabaceae), p. 212-227. In: AH. Paterson, TX. Austin (eds.). Genome Mapping in Plants. Landes Biomedical Press. 